\title{
APOPTOSIS, MEMORY CELL, AND T-HELPER LYMPHOCYTES BALANCE BETWEEN SEVERE AND MILD BRONCHIAL ASTHMA
}

\author{
Maha R. Abd El-wahed ${ }^{1}$, Ebtesam I. Ahmed ${ }^{2}$, Mohamed A. Mohamed ${ }^{3}$, Nora M. Said ${ }^{4}$ \\ ${ }^{1}$ Professor of clinical pathology, faculty of medicine, zagazig university, ${ }^{2}$ Professor of clinical \\ pathology, faculty of medicine, zagazig university, ${ }^{3}$ Professor of chest, faculty of medicine zagazig, \\ university, ${ }^{4}$ Assistant lecturer of clinical pathology, faculty of medicine zagazig university.
}

\begin{abstract}
Background: Bronchial asthma is a characterized by chronic inflammation with reversible airway obstruction and airway hyper-reactivity. In order to choose the most appropriate line of therapy we need to understand the sequence of inflammatory reaction at every stage of asthma.

Aim of the work: we aimed to study apoptosis tendency, $\mathrm{CD} 4^{+} / \mathrm{CD}^{+}$ratio, memory /naïve , and $\mathrm{T}$ - helper 1 and 2 cytokines in vitro synthesis from peripheral blood lymphocytes (PBL) in mild persistent asthma and severe persistent asthma during acute exacerbation attacks. Patients and methods: This study comprised 50 participants divided into three groups: Group I: 10 healthy volunteers, Group II: 20 patients of mild persistent asthma, Group III: 20 patients of severe persistent asthma. All members of this study were subjected to: Immunophenotyping by flow-cytometry. Lymphocyte populations were analyzed by using $\mathrm{CD}^{+} \mathrm{CD}^{+}$( $\mathrm{T}$ helper cells), $\mathrm{CD}^{+} \mathrm{CD}^{+}$( $\mathrm{T}$ cytotoxic cells), $\mathrm{CD}^{+} / \mathrm{CD}^{+}$ratio, BCL2, $\mathrm{CD} 45 \mathrm{RO}^{+}$(memory $\mathrm{T}$ cells), and $\mathrm{CD}^{+} 5 \mathrm{RA}^{+}$(naïve $\mathrm{T}$ cells) markers with calculation of $\mathrm{CD}^{2} 5 \mathrm{RO}^{+} / \mathrm{CD}^{2} 5 \mathrm{RA}^{+}$ratio and Th2/Th1 cytokines profile, in the form of IL-4/IFN- $\gamma$ ratio by Enzyme linked immunossorbant assay (ELISA). Results: We found an elevation in CD45RO and CD45RO ${ }^{+} / \mathrm{CD}_{4}$ RA $\mathrm{R}^{+}$ratio of $\mathrm{T}$ lymphocytes in severe than in mild asthmatics. Bcl-2 was elevated in severe asthma in relation to mild asthma and healthy group. While, no significant difference could be detected in CD4+/CD8+ ratio among the three groups. IL-4 and IL-4/ IFN- $\gamma$ ratio were increased in the mild and severe groups compared to the control group. Conclusion: The immune reactions differs greatly according to the severity of asthma, with more memory $\mathrm{T}$ cells, longer life span of PBL and a greater role of Th1 cytokines.
\end{abstract}

Key Words: asthma, Th1, Th2, IL-4, IFN- $\gamma$

\section{INTRODUCTION}

A sthma is a common disease manifesting by recurrent exacerbations resulting in changes in the structure of the airways. It is associated with swelling of the bronchial tubes which leads to narrowing of the airways. ${ }^{1}$ The pathogenesis of asthma relies mainly on chronic inflammation which results in airway obstruction and hyperresponsi-veness. ${ }^{2}$ Asthma was classified by the united states National Heart, Lung and Blood Institute into mild intermittent asthma, mild persistent asthma, moderate persistent asthma and severe persistent asthma. ${ }^{3}$

Defective apoptosis was implicated in the chronicity of asthma leading to persistence of hazardous inflammatory reactions and harmful effects of immune cells accumulation. ${ }^{4}$ All available information from both animal models and human studies emphasize the great role of $\mathrm{T}$ helper2 (Th2) cytokines in the pathogenesis of asthma. $^{5}$
Th2 lymphocytes secrete interleukin4(IL-4) and IL-13, which stimulate and sustain IgE synthesis and release from B cells, and IL-5 which leads to recruitment of eosinophils into bronchial walls and, directly or indirectly, causes bronchial hyper-responsiveness. Th1 cells secrete INF- $\gamma$ following activation. They are implicated in the initiation of inflammatory reactions leading to tissue damage and destruction. ${ }^{6}$

A great controversy was found around the role of $\mathrm{CD}^{+} \mathrm{T}$ cells in the pathology of bronchial asthma. A previous study found a correlation between $\mathrm{CD}^{+} \mathrm{T}$ lymphocytes activity and the pathogenesis of asthma. ${ }^{7}$ Another study demonstrated the ability of $\mathrm{CD} 8^{+} \mathrm{T}$ lymphocytes to secrete Th2 cytokines and their vital role in allergic inflammatory reactions and airway hyperresponsiveness. The identification of allergen specific $\mathrm{CD}^{+} \mathrm{T}$ cells provided another evidence for the great part played by $\mathrm{CD} 8^{+} \mathrm{T}$ lymphocytes 
in the pathology and acute exacerbations of asthma.

It has been shown that the increase of $\mathrm{CD}_{45 \mathrm{RO}^{+}} \mathrm{PBL}$ and $\mathrm{CD} 45 \mathrm{RO} / \mathrm{CD} 45 \mathrm{RA}$ ratio may explain the persistent airway inflammation of asthma. Chronic inflammation in an asthmatic subject may be attributed to the elevation in primed memory $\mathrm{T}$ lymphocytes, $\mathrm{CD} 45 \mathrm{RO}$, in the lung and peripheral blood. ${ }^{8}$

The aim of this work was to study apoptosis tendency, CD4/CD8 ratio, CD45RO/ CD45RA ratio and T helper 1 and Th2 cytokines in vitro synthesis from peripheral blood lymphocytes in mild and severe persistent asthma patients.

\section{PATIENTS AND METHODS}

The present study was conducted at Clinical Pathology and Medical chest Departments, Faculty of Medicine, Zagazig University Hospitals. Fifty participants were included in this study: Group I : 10 healthy volunteers they were 6 male and 4 female their age ranged from 28-49 years with a mean age $37.4 \pm 7.8$ years. Group II: 20 patients of mild persistent asthma they were 12 male and 8 female their age ranged from 27-52 years with a mean age 37.4 \pm 9.9 years.Group III: 20 patients with severe persistent asthma their age ranged 26-55 years with a mean age $40.1 \pm 10.7$ years.

Method: all members of this study were subjected to: thorough history taking , clinical examination, Routine laboratory investigations: CBC by " Sysmex S.F. 3000 ", stained smear for morphological examination, liver and kidney function tests by "Dimension RxL Max". Peak expiratory flow rate (PEFR) using Wright peak flow meter, Spirometric ventilatory pulmonary function testing and Arterial blood gases analysis. Special investigations: Immunophenotyping by flowcytometry (Biolegend, USA). Lymphocyte populations were analyzed by using $\mathrm{CD}^{+} \mathrm{CD}^{+}$ External standard dilution was prepared in tubes. $100 \mu \mathrm{l}$ standard dilutions was added in the microwell strips in duplicate. $50 \mu 1$ of Assay Buffer was added to sample wells. $50 \mu 1$ Sample was added, in duplicate, to prepared sample wells. $100 \mu \mathrm{l}$ Assay Buffer was added to blank wells. $50 \mu \mathrm{l}$ of prep-ared Biotin-Conjugate was added to all
(T helper cells), $\mathrm{CD}^{+} \mathrm{CD}^{+}$( $\mathrm{T}$ cytotoxic cells), $\mathrm{CD} 4 / \mathrm{CD} 8$ ratio, BCL2, CD45RO ${ }^{+}$(memory $\mathrm{T}$ cells), and CD45RA ${ }^{+}$(naïve T cells) markers with calculation of $\mathrm{CD}^{4} 5 \mathrm{RO}^{+} / \mathrm{CD} 45 \mathrm{RA}^{+}$and $\mathrm{Th} 2 /$ Th1 cytokines ratio in the form of IL-4/ IFN- $\gamma$ ratio by Enzyme linked immunossorbant assay (ELISA).

\section{Immunophenotyping of peripheral blood} lymphocytes:

The antibodies used were supplied by Biolegend (BD, USA). They included: antihuman CD3FITC conjugated, antihuman CD4 FITC conjugated, antihuman CD8 PE conjugated, antihuman CD45RO PE conjugated, antihuman CD45RA PE conjugated, antihuman BCL2 FITC conjugated and negative isotypic control for determining the non-specific binding of the monoclonal antibodies (MoAbs). The analysis of lymphocytes was done by flow cytometry using CELLQuest TM software.

Percentage of Positive cells among gated lymphocytes was defined for each marker. $-\mathrm{CD}^{+} / \mathrm{CD}^{+}$ratio and $\mathrm{CD} 45 \mathrm{RO}^{+} / \mathrm{CD}^{+} 5 \mathrm{RA}^{+}$ ratio were calculated.

\section{Separation of peripheral blood mononuclear cells}

Peripheral blood mononuclear cells (PBMN) were isolated with the gradient density sedimentation technique by Ficoll hypaque solution (Sigma). ${ }^{9}$ Lymphocytes count was adjusted to $1 \times 10^{6}$ cells $/ \mathrm{mL}$, followed by incubation for 3 days at $37^{\circ} \mathrm{C}$ in a 6 well culture plate containing $1 \mathrm{~mL}$ complete RPMI-1640 medium (Sigma) with $10 \%$ human $\mathrm{AB}$ serum, $200 \mathrm{U} / \mathrm{mL}$ penicillin $\mathrm{G}$ and $200 \mu \mathrm{g} / \mathrm{mL}$ streptomycin. On the fourth day, centrifugation of the mixture was done at $2000 \mathrm{~g}$ for 5 minutes, and the supernatant was taken in two sterile tubes and kept in $-80^{\circ}$ to be used for ELISA.

Enzyme-linked Immunosorbent Assay for measurement of IL-4and IFN- $\gamma$ :

wells. Microwell strips were covered and incubated 2 hours at room temperature $\left(18-25^{\circ} \mathrm{c}\right)$ in the dark. Microwell strips were washed 3 times.100 $\mu$ l Streptavidin-HRP was added to the wells. Then microwells were kept for1 hour at $\left(18-25^{\circ} \mathrm{c}\right)$. The wash was repeated for 3 times. Then $100 \mu$ l of the TMB Substrate Solution was 
delivered to the wells. The microwells were kept for 10 minutes at $\left(18-25^{\circ} \mathrm{c}\right) .100 \mu 1$ of the Stop Solution was delivered to all wells. Then color intensity was measured at $450 \mathrm{~nm}$.
The data were tabulated and statistically analyzed using Microsoft Office Excel 2007 and Statistical package for Social Sciences version 17 (SPSS: An IBM Company).

\section{RESULTS}

The results of our study are statistically analyzed and summarized in the following tables (1-7).

Table (1): The mean value of $\mathrm{CD} 4^{+}, \mathrm{CD} 8^{+}$percentages and $\mathrm{CD} 4^{+} / \mathrm{CD} 8^{+}$ratio among studied groups

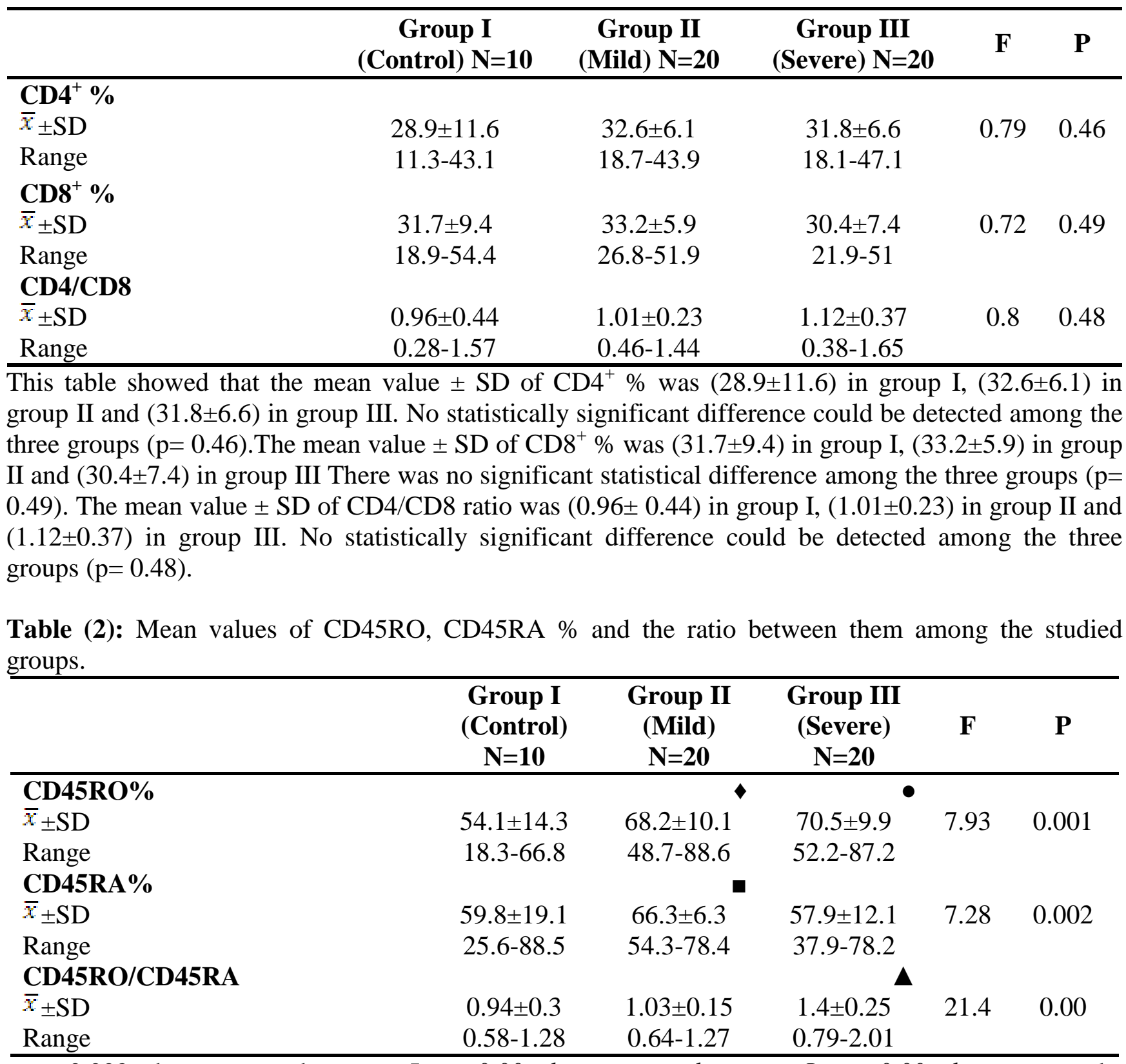

$\bullet p=0.002$ when compared to group $\mathrm{I}, \bullet p=0.00$ when compared to group $\mathrm{I}, \mathbf{\nabla} \mathrm{p}=0.00$ when compared to group II,

$\Delta \mathrm{p}=0.00$ when compared to group I \&II. 
This table showed that the mean value of $\mathrm{CD} 45 \mathrm{RO} \% \pm \mathrm{SD}$ in group I was $(54.1 \pm 14.3)$, in group II was $(68.2 \pm 10.1)$ and in group III was (70.5 \pm 9.9$)$. There was a high statistical significant difference among the three groups $(\mathrm{p}=0.001)$. The mean value of CD45RA\% \pm SD was $(59.8 \pm 19.1)$ in group $\mathrm{I},(66.3 \pm 6.3)$ in group II and (57.9 \pm 12.1$)$ in group III. A significant statistical difference was found among the three groups, $\quad(p=0.002)$. The mean value of $\mathrm{CD} 45 \mathrm{RO} / \mathrm{CD} 45 \mathrm{RA}$ ratio $\pm \mathrm{SD}$ was $(0.94 \pm 0.3)$ in group I, $(1.03 \pm 0.15)$ in group II and $(1.4 \pm 0.25)$ in group III. There was high statistical significant difference among the three groups, $(\mathrm{p}=0.00)$.

A significant elevation of $\mathrm{CD}^{4} 5 \mathrm{RO}^{+} \%$ was found in the mild group compared to the control group $(\mathrm{p}=0.002)$. Also there was a highly significant elevation in the severe group compared to the control group $(\mathrm{p}=0.00)$. While no statistically significant difference could be detected between the patient groups $(\mathrm{p}=0.51)$.

No statistically significant difference could be detected in CD45RA ${ }^{+} \%$ between control and mild group $(\mathrm{p}=0.17)$, also no significant difference between control and severe group $(\mathrm{p}=0.09)$. While there was a highly significant reduction in the severe group compared to the mild group $(\mathrm{p}=0.00)$.

No significant difference of CD45RO/ CD45RA ratio was found between control and mild group ( $\mathrm{p}=0.27)$. While there was a highly significant elevation in the severe group compared to the control and mild groups $(\mathrm{p}=0.00)$.

Table (3): Median value of Bcl2 \% among studied groups

\begin{tabular}{lccccc}
\hline & $\begin{array}{c}\text { Group I } \\
\text { (Control) } \\
\mathbf{N = 1 0}\end{array}$ & $\begin{array}{c}\text { Group II } \\
(\mathbf{M i l d}) \\
\mathbf{N = 2 0}\end{array}$ & $\begin{array}{c}\text { Group III } \\
\text { (Severe) } \\
\mathbf{N = 2 0}\end{array}$ & $\mathbf{F}$ & $\mathbf{P}$ \\
\hline Bcl2\% & & & & & \\
Median & 14.8 & 12.5 & 25.8 & & \\
$\overline{\boldsymbol{x}}_{ \pm S D}$ & $13.7 \pm 5$ & $12.4 \pm 8.7$ & $31.8 \pm 17.2$ & 13.9 & 0.00 \\
Range & $1.6-19.5$ & $0.12-28.9$ & $10.7-73.7$ & & \\
\hline
\end{tabular}

$\checkmark \mathrm{p}=0.00$ when compared to group I \& II.

This table showed that the median value of $\mathrm{Bcl} 2 \%$ was (14.8) in group I, (12.5) in group II and (25.8) in group III. A highly significant difference was found among the studied groups $(\mathrm{p}=0.00)$.
No significant difference was found in the median value of $\mathrm{Bcl} 2$ between control and mild groups $(\mathrm{p}=0.78)$. While there was a highly significant elevation in the severe group compared with both the control and mild groups $(\mathrm{p}=0.00)$. 
Table (4): The level of IL-4, INF- $\gamma$ and IL-4 / INF- $\gamma$ ratio among the studied groups

\begin{tabular}{|c|c|c|c|c|c|}
\hline & $\begin{array}{c}\text { Group I } \\
\text { (Control) } \\
\mathrm{N}=10 \\
\end{array}$ & $\begin{array}{c}\text { Group II } \\
\text { (Mild) } \\
\mathbf{N = 2 0} \\
\end{array}$ & $\begin{array}{c}\text { Group III } \\
\text { (Severe) } \\
\mathrm{N}=\mathbf{2 0} \\
\end{array}$ & KW & $\mathbf{P}$ \\
\hline $\begin{array}{c}\text { IL-4 pg/ml } \\
\text { Median } \\
\bar{x}_{ \pm S D} \\
\text { Range }\end{array}$ & $\begin{array}{c}1.3 \\
2.6 \pm 2.5 \\
1-8\end{array}$ & $\begin{array}{c}18 \boldsymbol{\Delta} \\
20.4 \pm 15.2 \\
1-58\end{array}$ & $\begin{array}{c}8 \\
9.3 \pm 5.7 \\
2.4-27\end{array}$ & 20.2 & 0.00 \\
\hline $\begin{array}{c}\text { INF- } \gamma \text { pg/ml } \\
\text { Median } \\
\bar{x}_{ \pm S D} \\
\text { Range }\end{array}$ & $\begin{array}{c}4.3 \\
5.4 \pm 5.1 \\
0.2-15\end{array}$ & $\begin{array}{c}3.9 \\
5.8 \pm 5 \\
0.6-18\end{array}$ & $\begin{array}{c}8.5 \\
10.6 \pm 9.8 \\
0.1-38\end{array}$ & 4.02 & 0.12 \\
\hline $\begin{array}{c}\text { IL-4 / INF- } \boldsymbol{\gamma} \\
\text { Median } \\
\bar{x}_{ \pm S D} \\
\text { Range }\end{array}$ & $\begin{array}{c}0.41 \\
3.6 \pm 9.3 \\
0.07-30\end{array}$ & $\begin{array}{c}3.05 \\
9.3 \pm 14.5 \\
0.42-50\end{array}$ & $\begin{array}{c}0.95 \\
10.1 \pm 25.4 \\
0.06-95\end{array}$ & 11.7 & 0.003 \\
\hline
\end{tabular}

This table showed that the median value of IL-4 was $(1.3 \mathrm{pg} / \mathrm{ml})$ in group $\mathrm{I},(18 \mathrm{pg} / \mathrm{ml})$ in group II and $(8 \mathrm{pg} / \mathrm{ml})$ in group III. There was a highly significant difference among studied groups $(\mathrm{p}=0.00)$. The median value of INF- $\gamma$ was $(4.3 \mathrm{pg} / \mathrm{ml})$ in group I, $(3.9 \mathrm{pg} / \mathrm{ml})$ in group II and $(8.5 \mathrm{pg} / \mathrm{ml})$ in group III. No statistically significant difference could be detected among studied groups $(\mathrm{p}=0.12)$. The median value of IL-4 / INF- $\gamma$ ratio was (0.41) in group I, (3.05) in group II and (0.95) in group III. A significant difference was found among studied groups $(\mathrm{p}=0.003)$.
There was a highly significant elevation of IL-4 in the mild group compared to the control group $(\mathrm{p}=0.00)$. Also there was a highly significant elevation in the severe group compared to the control group $(p=0.00)$. While a significant elevation was found in the mild group compared to the severe group $(\mathrm{p}=0.025)$. There was a significant elevation of IL-4/INF- $\gamma$ ratio in the mild group compared to the control and severe groups $\quad(p=0.002), \quad(p=0.015)$ respectively. While No statistically significant difference could be detected between control and severe groups $(\mathrm{P}=0.16)$.

Table (5): Correlation between $\mathrm{CD} 45 \mathrm{RO} \%$ and the degree of asthma among the patient groups:

\begin{tabular}{|c|c|c|c|c|}
\hline $\mathrm{C}_{\mathrm{CD45RO \%}}^{\text {Parameter }}$ & $\begin{array}{c}\text { Frequency of } \\
\text { symptoms/ week }\end{array}$ & $\begin{array}{l}\text { Frequency of } \\
\text { nocturnal } \\
\text { symptoms / } \\
\text { month }\end{array}$ & $\begin{array}{c}\mathrm{FEV}_{1} \% \\
\text { predicted }\end{array}$ & $\begin{array}{c}\text { FEV } 1 \text { after } \\
\text { salbutamol\% } \\
\text { predicted }\end{array}$ \\
\hline \multicolumn{5}{|l|}{ Group II (mild group) } \\
\hline $\mathbf{r}$ & 0.367 & 0.488 & -0.482 & -0.485 \\
\hline $\mathbf{p}$ & 0.101 & 0.025 & 0.027 & 0.026 \\
\hline \multicolumn{5}{|l|}{ Group III (severe group) } \\
\hline $\mathbf{r}$ & --------- & 0.231 & -0.301 & -0.311 \\
\hline p & --------- & 0.342 & 0.211 & 0.195 \\
\hline
\end{tabular}


This table showed that, in the mild group, a significant positive correlation was found between $\mathrm{CD} 45 \mathrm{RO} \%$ and the frequency of nocturnal symptoms $(\mathrm{r}=0.488, \mathrm{p}=0.025)$. While a significant negative correlation was found between $\mathrm{CD} 45 \mathrm{RO} \%$ and $\mathrm{FEV}_{1} \%$ predicted $(\mathrm{r}=$ $0.482, \mathrm{p}=0.027)$ and also there was a significant negative correlation between $\mathrm{CD} 45 \mathrm{RO} \%$ and $\mathrm{FEV}_{1} \%$ predicted after salbutamol $(r=-0.485, \quad p=0.026)$. However, there was no significant correlation between
$\mathrm{CD} 45 \mathrm{RO} \%$ and frequency of symptoms ( $\mathrm{r}=$ $0.367, \mathrm{p}=0.101$ ).

While, in the severe group, no statistically significant correlation could be found between $\mathrm{CD} 45 \mathrm{RO} \%$ and neither the frequency of nocturnal symptoms, nor FEV1\% predicted nor FEV $1 \%$ predicted after salbutamol $(\mathrm{r}=0.231, \mathrm{p}=$ $0.342),(\mathrm{r}=-0.301, \mathrm{p}=0.211),(\mathrm{r}=-0.311, \mathrm{p}=$ $0.195)$ respectively. CD45-RO\% could not be correlated to the frequency of symptoms / week because all patients in the severe group had continuous symptoms all over the week.

Table (6): Correlation between CD45RA\% and the degree of asthma among the patient groups:

\begin{tabular}{|c|c|c|c|c|}
\hline Parameter & $\begin{array}{c}\text { Frequency of } \\
\text { symptoms/ week }\end{array}$ & $\begin{array}{l}\text { Frequency of } \\
\text { nocturnal } \\
\text { symptoms / } \\
\text { month }\end{array}$ & $\begin{array}{l}\mathrm{FEV}_{1} \% \\
\text { predicted }\end{array}$ & $\begin{array}{c}\mathrm{FEV}_{1} \text { after } \\
\text { salbutamol \% } \\
\text { predicted }\end{array}$ \\
\hline \multicolumn{5}{|l|}{ Group II (mild group) } \\
\hline $\mathbf{r}$ & -0.600 & -0.399 & 0.517 & 0.510 \\
\hline p & 0.004 & 0.73 & 0.016 & 0.018 \\
\hline \multicolumn{5}{|l|}{ Group III (severe group) } \\
\hline $\mathbf{r}$ & --------- & -0.421 & 0.388 & 0.219 \\
\hline p & --------- & 0.072 & 0.101 & 0.369 \\
\hline
\end{tabular}

This table showed that, in the mild group, a significant negative correlation was revealed between CD45RA\% and the frequency of symptoms / week $(\mathrm{r}=-0.600, \mathrm{p}=0.004)$. While a significant positive correlation was revealed between CD45RA\% and both FEV $1 \%$ predicted and $\mathrm{FEV}_{1} \%$ predicted after salbutamol $(\mathrm{r}=0.517, \mathrm{p}=0.016),(\mathrm{r}=0.510, \mathrm{p}=$ 0.018 ) respectively. However, no significant correlation could be detected between
CD45RA\% and the frequency of nocturnal symptoms / month $(\mathrm{r}=-0.399),(\mathrm{p}=0.73)$.

In the severe group, no significant correlation could be found between CD45RA\% and neither the frequency of nocturnal symptoms/month, nor $\mathrm{FEV}_{1} \%$ predicted, nor $\mathrm{FEV}_{1} \%$ predicted after salbutamol $(\mathrm{r}=-0.421, \mathrm{p}=0.072), \quad(\mathrm{r}=$ $0.388, \quad p=0.101), \quad(r=0.219, \quad p=0.369)$ respectively.

Table (7): Correlation between CD45RO / CD45RA ratio and the degree of asthma among the patient groups:

\begin{tabular}{|c|c|c|c|c|}
\hline Parameter & $\begin{array}{c}\text { Frequency of } \\
\text { symptoms/ week }\end{array}$ & $\begin{array}{c}\text { Frequency } \\
\text { of nocturnal } \\
\text { symptoms / } \\
\text { month }\end{array}$ & $\begin{array}{l}\mathrm{FEV}_{1} \% \\
\text { predicted }\end{array}$ & $\begin{array}{c}\text { FEV }_{1} \text { after } \\
\text { salbutamol \% } \\
\text { predicted }\end{array}$ \\
\hline \multicolumn{5}{|l|}{ Group II (mild group) } \\
\hline $\mathbf{r}$ & 0.704 & 0.728 & -0.821 & -0.821 \\
\hline $\mathbf{p}$ & 0.00 & 0.00 & 0.00 & 0.00 \\
\hline \multicolumn{5}{|l|}{ Group III (severe group) } \\
\hline $\mathbf{r}$ & --------- & 0.669 & -0.718 & -0.511 \\
\hline $\mathbf{p}$ & --------- & 0.002 & 0.00 & 0.025 \\
\hline
\end{tabular}


This table showed that, in the mild group, a significant positive correlation was detected between CD45RO / CD45RA ratio and the frequency of symptoms / week and the frequency of nocturnal symptoms/month ( $\mathrm{r}=$ $0.704, \quad \mathrm{p}=0.00) \quad(\mathrm{r}=0.728, \quad \mathrm{p}=0.00)$ respectively. While there was a significant positive correlation between CD45RO/CD45RA and the frequency of
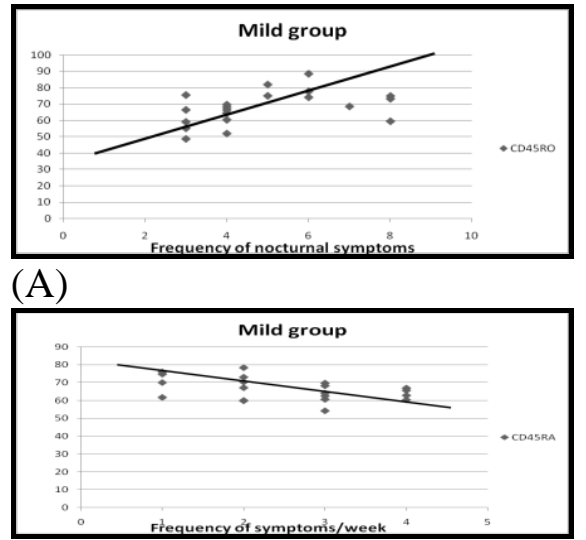

(C)

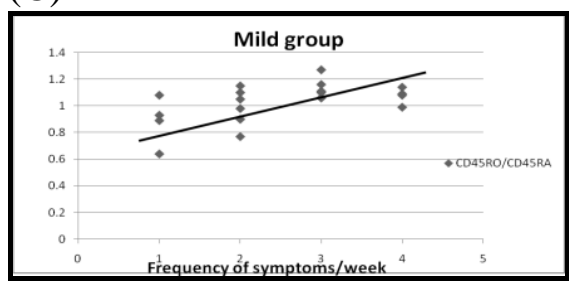

(E)

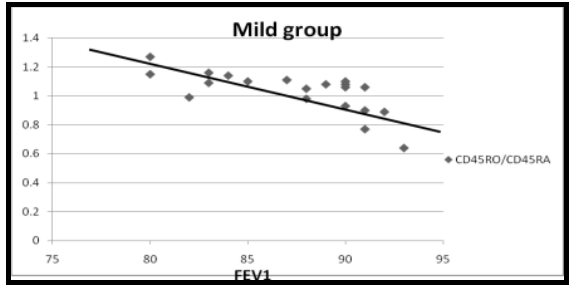

nocturnal symptoms / month in the severe group $(\mathrm{r}=0.699, \mathrm{p}=0.002)$. Moreover, a significant negative correlation was found between $\mathrm{CD} 45 \mathrm{RO} / \mathrm{CD} 45 \mathrm{RA}$ ratio and $\mathrm{FEV}_{1} \%$ predicted and FEV1 \% predicted after salbutamol in both mild and severe groups $(\mathrm{r}=$ $0.821, \mathrm{p}=0.00),(\mathrm{r}=0.821, \mathrm{p}=0.00),(\mathrm{r}=-0.718$, $\mathrm{p}=0.00),(\mathrm{r}=0.511, \mathrm{p}=0.025)$ respectively.

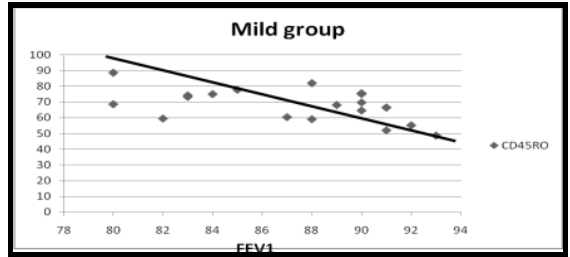

(B)

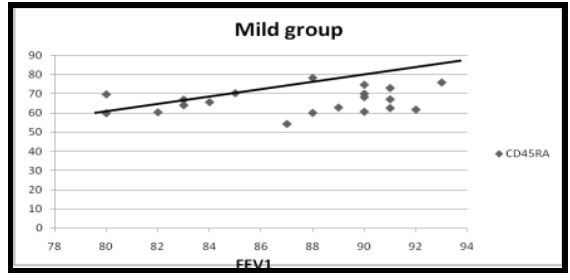

(D)

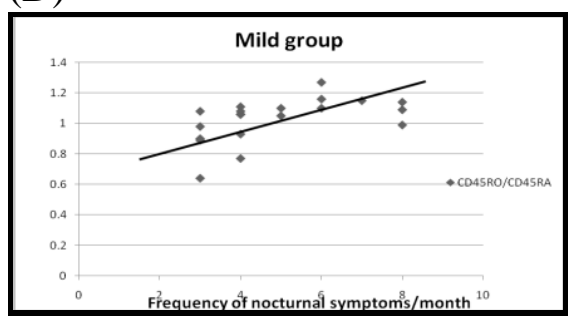

(F)

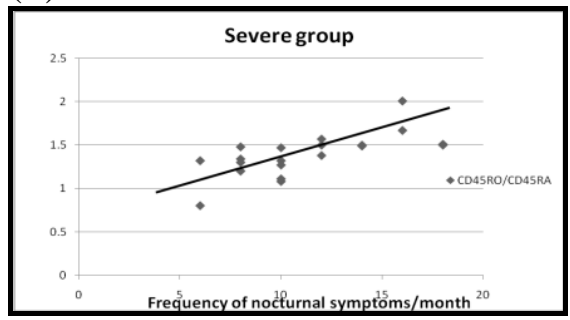

$(\mathrm{H})$

(G)

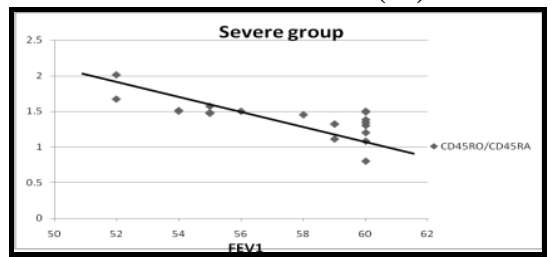

(I)

Figure (1): A) Significant positive correlation between CD45RO and frequency of noctu symptoms in the mild group. B) Significant negative correlation between CD45RO and FEV ${ }_{1}$ in mild group. C) Significant negative correlation between CD45RA and frequency of symptor week in the mild group. D) Significant positive correlation between CD45RA and FEV in $_{1}$ the $r$ 
group. E) Significant positive correlation between CD45RO /CD45RA ratio and frequency symptoms/week in the mild group. F) Significant positive correlation between CD45RO/CD45 ratio and frequency of nocturnal symptoms / month in the mild group. G) Significant nega correlation between CD45RO/ CD45RA ratio and $\mathrm{FEV}_{1}$ in the mild group. $\mathrm{H}$ ) Significant posi correlation between CD45RO / CD45RA ratio and frequency of nocturnal symptoms/month in severe group. I) Significant negative correlation between CD45RO / CD45RA ratio and FEV the severe group.
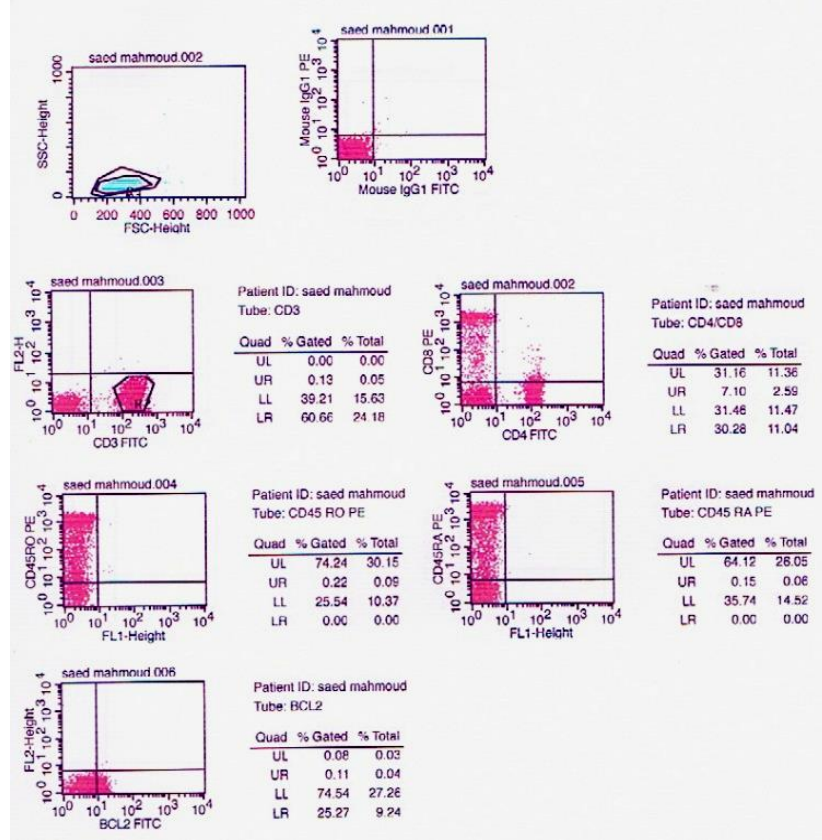

(A)
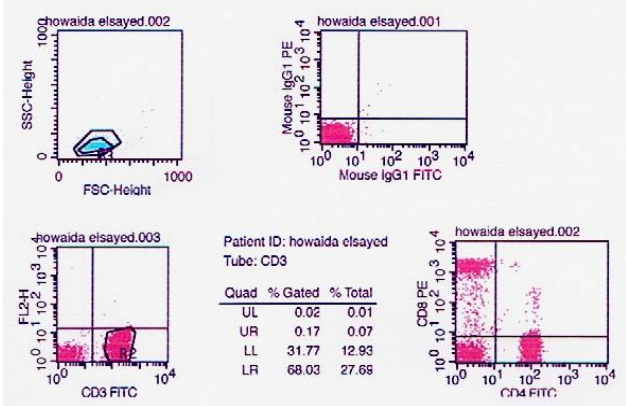

Patient iD: howaida elsay Tube: $\mathrm{CD} 4 \mathrm{COB}$ \begin{tabular}{ccc} 
Ouad & $\%$ Gated $\%$ Total \\
\hline UL & 24.84 & 10.78
\end{tabular} $\begin{array}{rrr}\text { UR } & 4.68 & 2.02 \\ \text { L } & 29.92 & 12.96\end{array}$
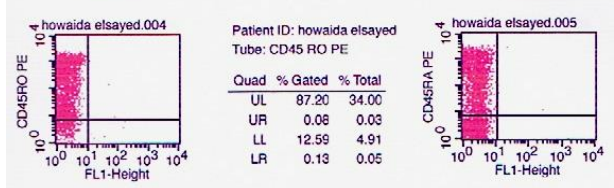
Tube: CD45 RAPE \begin{tabular}{ccc} 
Quad $\%$ Gated $\%$ Total \\
\hline UL & 57.61 & 22.78
\end{tabular} \begin{tabular}{lll} 
UR & 0.13 & 0.05 \\
\hline & 4224 & 1071
\end{tabular} $\begin{array}{rrr}\text { UL } & 42.24 & 16.71 \\ \text { LF } & 0.03 & 0.01\end{array}$

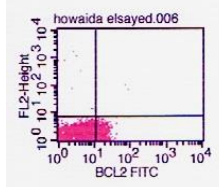

Patient ID: howaida elsayed

Tube: BCL2

\begin{tabular}{ccc} 
Ouad \% Gated \% Total \\
\hline UL & 0.23 & 0.10
\end{tabular}

\begin{tabular}{rrr} 
UR & 0.05 & 0.02 \\
\hline & 0.02 & 29.93
\end{tabular}

$\begin{array}{lll}\text { LR } & 68.02 & 29.93 \\ \text { LR } & 31.70 & 13.95\end{array}$

(B)

Figure (2): A) Immunophenotyping of a mild asthmatic patient. B) Immunophenotyping of a severe asthmatic patient.

\section{DISCUSSION}

The site of inflammatory injury in patients with asthma contains large amounts of activated lymphocytes with significantly prolonged survival. In normal situations, the immune system eli-minates hyperactivated lymphocytes through the activation induced cell death (AICD) mechan-ism, which effectively prevents the occurrence of immune inflammatory injury and autoimmune diseases. $^{10}$ Thus, defective AICD and significantly enhanced proliferation may contribute to inflammatory infiltration and prolonged survival of CD4+ $\mathrm{T}$ lymphocytes in patients with asthma. ${ }^{11}$
Our study was carried out to reveal the changes in peripheral blood lymphocytes CD4+/CD8+ ratio, Bcl-2, $\mathrm{CD} 45 \mathrm{RO}+1 \quad \mathrm{CD} 45 \mathrm{RA}+$ (memory/naïve ) ratio and Th2/ Th1 profile in the form of detecting IL-4 and IFN- $\gamma$ synthesized spontaneously in vitro by PBL and their ratio and in healthy subjects, mild, and severe persistent asthma patients. This information is crucial for understanding the sequence of the immune reaction in different grades of asthma severity. This could guide the clinician to choose the best strategy of treatment that targets the real causative factors.

The present study showed a higher prevalence of asthma among males with male to female ratio 
(2.1/1) this could be attributed to the high prevalence of smoking among males in Egypt especially in the low socioeconomic level. These findings are in line with another study in Iran that reported a higher prevalence among males with a male to female ratio $(1.5 / 1){ }^{12}$ However, other studies have reported higher incidence of asthma among females. ${ }^{13,14}$

In our study, no significant difference could be detected in the percentage expression of $\mathrm{CD}^{+}$ nor $\mathrm{CD}^{+} \mathrm{T}$ cells between the control group and patient groups, also, no significant difference could be detected in the $\mathrm{CD} 4^{+} / \mathrm{CD}^{+}$ratio between control and patient groups.

Various factors are responsible for $\mathrm{CD}^{+} \mathrm{T}$ cell activation in asthma; these factors are mainly local within the airway of asthmatic patients. Alveolar macrophage in the inflammatory environment of chronic asthma might contribute to activation of CD4 T-lymphocytes. ${ }^{15}$ Also a recent in vitro study found that eosinophils recruited to the airway modulated $\mathrm{CD} 4+\mathrm{T}$ cell responses contributing to the pathogenesis of asthma characterized by eosinophilic airway inflammation. ${ }^{16} \mathrm{Th} 2$ cytokines switch antiviral CD8+ T cells to production of IL-5 resulting in more exacerbation of the allergic inflammation. And so, CD8+ T cell antiviral function would be inhibited along with CD8+ $\mathrm{T}$ cell-mediated exaggeration of the allergic inflammation. ${ }^{17}$

Our results could be explained by the results of Cho and his colleges. They found an increase in the spontaneous synthesis of IL-5 and IFN- $\gamma$ by CD8+ T cells in the sputum of asthmatic patients related to disease severity. While PB samples showed no differences between patient groups. These findings mean that observations on $\mathrm{PB} \mathrm{CD} 4+$ and $\mathrm{CD} 8+\mathrm{T}$ cells in the peripheral blood are not usually related to changes of CD4+ and CD8+ T cells of the airway. ${ }^{18}$ This results were supported by the results of Abdulamir et al, and Machura et al. ${ }^{3,7}$ On the contrary, Vos et.al reported a significant reduction in $\mathrm{CD}^{+} \mathrm{T}$ cells asthmatic children compared to healthy children. ${ }^{19}$

The present work demonstrates a highly significant elevation in the percentage expression of CD45RO cells in both asthmatic patient groups compared to control group. While, no statistically significant difference could be detected between the mild and severe groups. We also found a highly significant increase in the percentage expression of CD45RA cells in mild group compared to the severe group. While, no significant difference could be detected between the control group and both the mild and severe groups. Also, there was a highly significant elevation in the ratio between $\mathrm{CD} 45 \mathrm{RO} / \mathrm{CD} 45 \mathrm{RA}$ cells in severe asthmatic patients compared to control and mild groups. While, no significant difference could be detected between the mild and control groups.

These results demonstrated that the memory $T$ cells in $P B$ of patients with severe asthma were significantly increased and this may explain the persistence of inflammatory reactions in the lung. CD4+CD45RO+RA+ in asthmatic patient's blood, representing naïve to memory transitionnal phenotype, were expanded shortly after antigenic exposure providing evidence to how environmental factors play a role in allergy and asthma. ${ }^{20}$

Persistent inflammation in asthma requires the presence of an adequate amount of activated memory $\mathrm{T}$ lymphocytes. ${ }^{21}$ The percentage of CD45RO PBL in addition to CD45RO/CD45RA ratio were more elevated in patients with severe asthma than patients with mild asthma and control subjects. The high level of $\mathrm{CD} 45 \mathrm{RO} / \mathrm{CD} 45 \mathrm{RA}$ ratio and $\mathrm{Bcl} 2$ may point to that effector memory $\mathrm{T}$ cells may induce proinflammatory signals that leads to the sustained immune reaction in the airway of asthmatic patients. Decreased apoptosis of these cells increases their life span and so may prolong their effects. $^{3}$

Memory CD4 T cells perform many functions including the secretion of cytokines, these cytokines can control highly effective secondary responses through different mechanisms. As well as the enhancement of direct effector functions at late phases of the immune response, in addition to their important helper function for CD8 $\mathrm{T}$ cell and $\mathrm{B}$ cell activity. $^{22}$ Our results were supported by 
Abdulamir and his colleges, who found an increase in the percentage of CD45RO PBL as well as CD45RO/CD45RA ratio in patients with severe asthma compared to patients with mild asthma and healthy volunteers. ${ }^{3}$

On the contrary, Machura et al., reported that the percentage of $\mathrm{CD} 4+\mathrm{CD} 45 \mathrm{RO}+$ cells was reduced in asthma children compared to the healthy children with no correlation to the severity of asthma; however, the absolute counts showed no difference among the groups. $^{7}$ Another study revealed that CD4+CD45RO+ memory $\mathrm{T}$ cells was more elevated in asthma patients than in healthy subjects, while the CD4+CD45RA+ naïve $\mathrm{T}$ cells in $\mathrm{PB}$ showed no significant differences among the groups. ${ }^{20}$

The current study found a highly significant elevation in $\mathrm{Bcl} 2 \%$ expression on $\mathrm{T}$ cells of severe asthmatics compared to mild and control groups. While, no significant difference could be detected between mild group and control group. Abdulamir et.al found a high level of $\mathrm{NF}-\kappa \mathrm{B}$ expression only in severe asthmatic patients but not in mild asthmatic patients, this may explain why the $\mathrm{Bcl} 2$ was much higher in the severe group than the mild group. It was demonstrated that NF- $\kappa \mathrm{B}$ induces the expression and activity of $\mathrm{Bcl}-2$, which is a strong antiapoptotic molecule and inhibits the proapoptotic Bax molecules. $^{23}$

IL-4 downregulates Fas expression on T cells and induces Bcl-2 expression to inhibit apoptosis and promote proliferation. A previous study showed that both the serum IL-4 and Bcl2 expression by $\mathrm{CD} 4+\mathrm{T}$ cells were significantly increased in children with asthma. Accordingly, it can be speculated that apoptosis inhibition and enhanced proliferation of CD4+ $\mathrm{T}$ cells are related to this increase in IL-4 expression. ${ }^{11}$ Inflammation is the main character of asthma. Lymphocyte persistence may be responsible for the chronicity and persistence of airway infl-ammation. ${ }^{24}$ Abdulamir et.al concluded that antiapoptotic protein Bcl-2 can suppress the expre-ssion and activity of proapoptotic proteins Bax. Reduction of apoptosis, related to the increase in persistence, severity and chronicity of asthma pathogenesis, clarifies the role of prolonged survival of the primed PBL in the development of the disease. ${ }^{3}$

Previous studies demonstrated that reduced apoptosis may be responsible for the accumulation and persistence of memory lymphocytes in asthmatic patients. ${ }^{3,25}$ The result of this study is in agreement with another study showed that Bcl-2 expression by $\mathrm{T}$ helper cells was significantly increased in children with asthma. ${ }^{11}$ Also other studies revealed that both $\mathrm{Bcl} 2$ and $\mathrm{Bcl}-2 / \mathrm{Bax}$ ratio were significantly increased in patients with asthma compared to control group and a significant increase in severe asthma compared to mild asthma.,23

In our study we found a highly significant elevation in IL-4 level in asthmatic patient groups compared to the control group, while the in vitro synthesis of IL-4 in mild asthmatics was significantly increased compared to severe asthmatics. Though, we found no significant differ-ence of IFN- $\gamma$ level among the groups. Also, there was a significant elevation of IL$4 / \mathrm{INF}-\gamma$ ratio in the mild group compared to the control and severe groups.

A previous study suggested that imbalance in the apoptosis of Th1 and Th2 effector cells may result in more death in one subset than the other. Akdis et.al found a fraction of cutaneous lymphocyte antigen $\left(\mathrm{CLA}^{+}\right) \mathrm{CD}^{2} 5 \mathrm{RO}^{+} \mathrm{T}$ cells showing prove of in vivo initiated activation induced cell death (AICD). ${ }^{26}$

Apoptosis of PB T lymphocytes was affecting mainly the Th1 cells, explaining the increase in Th2 profile among individuals with atopic dermatitis. This may elucidate the lake of peripheral blood lymphocytosis in patients with atopic dermatitis, despite the accumulation of $\mathrm{T}$ cells in the skin to make eczematous lesions. The lake of survival signals and inhibitors of Fas pathway leads to a shift toward Th2 cytokines in $\mathrm{CD}_{45 \mathrm{RO}^{+}} \mathrm{T}$ cells and $\mathrm{CLA}^{+}$ $\mathrm{CD}^{2} 5 \mathrm{RO}^{+} \mathrm{T}$ cell clones. While high IFN- $\gamma-$ secreting Th1 cells in mice showed a shorter life span. ${ }^{26}$

A previous study found an increase in the percentage of $\mathrm{T}$ cells expressing $\mathrm{Th} 2$ cytokine 
mRNA in allergic inflammatory reactions. CD4+ $\mathrm{T}$ cells of allergic patients showed an abnormal in vitro synthesis of IL-4 and IL-5 triggered by antigens that are supposed to induce Th1 responses. ${ }^{27}$

Dendritic cells play a central role in directing the immune response toward various Th subsets according to the type of costimulatory factors. Recently, it has been found that severe asthma is associated with activation and differentiation of Th17 rather than Th2 lymphocytes. These events occur in asthma due to the defective function of specific regulatory $\mathrm{T}$ cells. ${ }^{28}$

Various studies were performed to study the $\mathrm{T}$ cell cytokines profile in asthma in adults and in children. Their results found a remarkable imbalance in cytokine profile associated with the development of this disease in both settings. ${ }^{29}$

IL-4 is the main Th2-related cytokine. TNF promotes aggregation of lymphocytes and secretion of Th2 cytokines to mediate inflammatory reactions. Kaminuma observed that IL-4 participates in the mediation of local tissue inflammatory infiltration in patients with asthma and also activates eosinophils and aggravates asthma symptoms. ${ }^{30}$ Furthermore, IL-4 participates in IgE generation through regulation of class switching. These observations indicate that IL-4, IL-10 and TNF are key players in respiratory inflammation in childhood asthma. ${ }^{31}$ Th1 cytokines, IFN- $\gamma$, seem to play an important role in the progression of asthma with increase in severity and chronicity. A previous report found an increase in $\mathrm{T}$ cells producing IFN- $\gamma$ in asthmatic patients compared with normal subjects. ${ }^{18}$

Th2 cytokines are the main trigger of inflammation in mild asthma due to the elevation of IL-4 level and reduction in the level of IFN- $\gamma$. However, Th1 cytokines gained a higher role as asthma became more severe and chronic because of the elevation of IFN- $\gamma$ in severe asthma. And so, IL-4/IFN- $\gamma$ ratio was significantly reduced in severe asthma patients compared to both mild asthma patients and healthy subjects. This finding partially antagonizes the Th2 hypothesis of asthma which explains both severe and mild asthma in the same way. ${ }^{3}$

Al-Daghri et al. reported a significant increase in IL-4 in severe asthmatic children compared to healthy children but they reported a significant decrease in IFN- $\gamma$ in severe asthmatic children compared to healthy children. ${ }^{29}$ On the contrary, Machura et.al found that the percentage pro-portions of CD4+ T cell staining positively for IL-4 and IFN- $\gamma$ in periphral blood were not significantly different in children with asthma and healthy children. While CD8+ T spontan-eously producing IL-4 was much higher in asthmatic children compared to healthy controls. ${ }^{32}$ Also, Abdulamir et.al found a significantly elevated level of IFN- $\gamma$ in severe asthmatic group compared to mild asthmatic group which was more elevated than in healthy subjects. While the level of IL-4 was significantly higher in mild asthmatics in comparison with severe asthmatics and healthy subjects. IL-4/ IFN- $\gamma$ ratio was remarkably reduced in severe asthma patients than in $\mathrm{HV}$ and mild asthma patients. ${ }^{3}$ We found a higher level of IFN- $\gamma$ among the severe asthmatic group compared to the control, however this elevation wasn't statistically significant. This could be explained by exhaustion of the Th2 cells in vivo especially in the severe asthmatic group with sustained symptoms, together with abruption of the antigenic stimulation that resulted in lower level of its activity in cultures.

\section{CONCLUSION}

The inflammatory response in mild persistent asthma showed that both CD4+ and CD8+ cells influence the development of asthma with no skewing to one of them over the other. These reactions were controlled mostly by $\mathrm{Th} 2$ cytokines, with less memory cells and shorter life spans of PBL. Severe persistent asthma showed also that CD4+ and CD8+ cells influence the development of asthma with no skewing to one of them over the other. The inflammatory reactions appear to be controlled by both Th2 and Th1 cytokines, with enlargement of memory compartment resulting in more prolonged inflammation. It also 
showed prolonged survival of PBL due to reduced apoptosis, with predilection to CD45RO+ cells. This study provides guidance regarding the adjustment of asthma management according to the class of asthma.

\section{RECOMMENDATION}

Future research is required to confirm the role of IFN- $\gamma$ in the pathogenesis of severe asthma. Newly described $\mathrm{T}$ helper subsets were suspected to have a role in the pathogenesis of asthma specially Th17 and T regulatory cells. Therefore future research is needed to prove their role in asthma. An extended follow up study is recommended in order to assess the memory $\mathrm{T}$ cell compartment and apoptosis with different lines of treatment.

\section{REFERENCES}

1-Bosse Y, Rola-Pleszczynski M (2007): Controversy surrounding the increased expression of TGF beta 1 in asthma. Respir Res; 8:66-76.

2-Hanania NA (2008): Targeting airway inflammation in asthma: current and future therapies. Chest; 133:989-998.

3-Abdulamir AS, HafidhRR, Abubakar F, Abbas KA (2008): Changing survival, memory cell compartment and $\mathrm{T}$ helper balance of lymphocytes between severe and mild asthma. BMC Immunology; 9:73-81.

4-Sturum A, De Souza HS, Ficocchi C (2008): Mucosal $\mathrm{T}$ cell proliferation and apoptosis in inflammatory bowel disease.Curr Drug Targets; 9:381-7.

5-Wills-Karp M (1999): Immunologic basis of antigen-induced airway hyper-responsiveness. Annu Rev Immunol; 17:255-281.

6-Yssel H, Lecart S, Pene J (2001): Regulatory T cells and allergic asthma. Microbes and infection; 3:899-904.

7-Machura E, Mazur B, Pieniazek W, et al. (2008): Expression of naive/memory (CD45RA/CD45RO) markers by peripheral blood CD4+ and CD8+ T cells in children with asthma. Arch Immunol Ther Exp; 56: 55-62.

8-Seneviratne SL, Jones L, King AS, et al. (2002): Allergen specific CD8 (+) T cells and atopic diseases. J Clin Invest; 110:1283-1291.

9-Wahlstrom J, Berlin M, Skold CM, Wigzell H, Eklund A, Grunewald J(1999): Phenotypic analysis of lymphocytes and monocytes/macrophages in peripheral blood and bronchoalveolar lavage fluid from patients with pulmonary sarcoidosis. Thorax 1999, 54:339-46.

10-Budd RC (2001): Activation induced cell death. Curr Opin Immunol; 13: 356-62.

11-Jiang T, Sheng J, Qin Y, et al. (2014): Enhanced proliferation and defective activation induced cell death of CD4+ T cells in childhood asthma. Asian Pac J Allergy Immunol; 32: 75-83.

12-Nadi E, Hajilooi M, Babakhani D, Rafie I (2012): Platelet Endothelial Cell Adhesion Molecule-1 polymorphism in patients with bronchial asthma. Iran J Allergy Immunol ; 11(4): 276-281.

13-Olufemi O D, Cajetan CO, Adekunle OA, et al. (2013): Unmet needs in asthma treatment in a resource-limited setting: findings from the survey of adult asthma patients and their physicians in Nigeria. Pamj; 16:1-13.

14-Agrawal S, Pearce N, Ebrahim S (2013): Prevalence and risk factors for self-reported asthma in an adult Indian population: a cross-sectional survey. Int J Tuberc Lung Dis; 17(2): 275-282.

15-Herbet C, Scott M, Scruton K, et al. (2010): Alveolar macrophage stimulates enhanced cytokine production by pulmonary $\mathrm{CD}^{+} \mathrm{T}$ lymphocytes in an exacerbation of murine chronic asthma. Am J Pathol; 177: 1657-1664.

16-Shim EJ, Lee HS, Bang BR, et al. (2015): Eosinophils modulates $\mathrm{CD} 4^{+} \mathrm{T}$ cell responses via high mobility group Box-1 in the pathogenesis of asthma. Allergy Asthma Immunol Res; 7(2): 190194.

17-Betts RJ, Kemeny DM (2009): $\mathrm{CD}^{+} \mathrm{T}$ cells in asthma: friend or foe? Pharmacology\&Therapeutics; 121:123-131.

18-Cho S, Standicu L, Holgate S, Johnston S (2005): Increased Il-4, IL-5 and IFN- $\gamma$ in airway $\mathrm{CD}^{+} \mathrm{T}$ cells in atopic asthma. Am J Respir Crit Care Med; 171:224-230.

19-Vos G, Milush JM, Aaron J, et al. (2012): Peripheral CD8+ T-Cell levels are decreased in atopic wheezing children aged less than 4 years. J Investigo Allergol Clin Immunol; 22(6): 437-459.

20-Mahmoud F, Habeeb F, Arifhodzic N, et al. (2010): T Lymphocyte Activation Profiles in Peripheral Blood of Long- Versus Short-Term Residents of Kuwait: Comparison with Asthmatics. Ann Acade Med Singapore; 39:854-60.

21-Mineeve VN, Trofino VI, Nesterovich II, et al. (2008): Disturbance of apoptosis of peripheral blood lymphocytes in different varients of bronchial asthma. Ter Ark; 80:43-49. 
22-Mckinstry KK, Srutt TM, Swain SL (2010): The potential of CD4 $\mathrm{T}$ cell memory. Immunology; 130:1-9.

23-Abdulamir AS, Kadhim HS, Hafidh RR, et al. (2009): Severity of asthma: The role of CD25+, $\mathrm{CD} 30^{+}, \mathrm{NF}-\kappa \mathrm{B}$ and apoptotic markers. $\mathrm{J}$ Investig Allergol Clin Immunol; 19(3): 218-223.

24-Ohta K, Yamshita N (1999): Apoptosis of eosinophils and lymphocytes in allergic inflammation. J Allergy Clin Immunol; 104(1): 1421.

25-Lamb J, James A, Carroll N, et al. (2005): Reduced apoptosis of memory $\mathrm{T}$ cells in the inner airway wall of mild and severe asthma. Eur Respir J; 26:265-270.

26-Akdis M, Traumann A, Klunker S, et al. (2003): T helper (Th) 2 predominance in atopic diseases is due to preferential apoptosis of circulating memory/effector Th1 cells. FASEB Journal; 17: 1026-1035.

27-Mazzarella G, Bianco A, Catena E, et al. (2000): Th1/Th2 lymphocyte polarization in asthma. Allergy; 55:61-69.
28-Pelaia G, Vatrella A, Busceti MT, et al. (2015): Cellular mechanisms underlying eosinophilic and neutrophillic airway inflammation in asthma. Mediators Inflamm; 1-8.

29-Al-Daghri NM, Alokail MS, Draz HM, et al. (2014): Th1/Th2 cytokine pattern in arab children with severe asthma. Int J Clin Exp Med; 7(8): 2286-2291.

30-Kaminuma O, Mori A, Ogawa K, et al. (1999): Cloned Th cells confer eosinophilic inflammation and bronchial hyperrespons-ivness. Int Arch Allergy Immunol; 118:136-9.

31-Yang XX, Li FX, Wu YS, et al. (2011): Association of TGF-beta and IL13 gene polymorphisms with asthma in a Chinese population. Asian Pac J Allergy Immunol; 29: 2737.

32-Machura E, Mazur B, Rusek-zychma M, Barcczarnecka M (2010): Cytokine production by peripheral blood $\mathrm{CD}^{+}{ }^{+}$and $\mathrm{CD} 8^{+} \mathrm{T}$ cells in atopic childhood asthma. Clinical and developmental Immunology; 1-11. 